\title{
THE ROLE OF AIRBORNE GAMMA-RAY SPECTROMETRY IN BEDROCK MAPPING AND MINERAL EXPLORATION: CASB STUDIES FROM GRANITIC ROCKS WITHIN THE MEGUMA ZONB, NOVA SCOTIA
}

\author{
G.A. O'Reilly, M.C. Corey \\ Nova Scotia Department of Mines and Energy \\ P.O. Box 1087, Halifax, Nova Scotia B3J $2 \times 1$ \\ and \\ K.L. Ford \\ Geologlcal Survey of Canada \\ 601 Booth Street, Ottawa, Ontar10 KIA OE8
}

Date Rece1ved December 1, 1987

Date Accepted Apr11 8, 1988

\begin{abstract}
Fleld, petrographical and geochemical evidence collected from three case study areas within the peraluminous granites of the Meguma Zone indicates that airborne gamma-ray spectrometric data can be a valuable aid in bedrock mapping and mineral exploration. The three case study areas 1nclude the New Ross Pluton and Big Indian Polyphase Intrusive suite which underlie a portion of the central and eastern region of the $10,000 \mathrm{~km}^{2}$ South Mountain Batholith, and the Sangster Lake and Larrys River plutons from the eastern end of the Meguma Zone.

Ut111zing predominate1y the eU/eTh rat1o, it is shown that these data can delineate the various granit1c units which comprise large plutons and batholiths. A direct correlation is observed between areas of highest ratio response and the presence of small two-mica leucogranitic intrusive bodies. Conversely, areas underlain by biotite-rich monzogranit1c units possess the lowest rat10 response. The concentration of trace elements such as $U$. Th, $\mathrm{Rb}$, Sr, $\mathrm{Zr}$ and T1 within the various units confirm these observations and indicate that the variation in eU/eTh may be attributed to the degree of magmatic differentiation.

The case studies presented in this paper also indicate that factors other than bedrock composition can influence the airborne radioelement response of a given area. For example, parameters such as type and style of mineralization, type and degree of fluid interaction, and also the provenance and thickness of till deposits may all play an important cumulative role in the determination of the airborne spectrometric signature over an area. Accordingly, any geological investigation or mineral exploration venture ut1lizing such data must be prepared to address these vartables.
\end{abstract}

La collecte de donnes de terrain, petrographiques et geochimiques en tro1s sites représentatifs au sein de granites peralumineux de la Zone de Meguma indique que la spectrometrie aeroportée a rayons gamma peut s'averer un outil fort utile a la cartographie du socle et a l'exploration minérale. Parmi ces sites, on retrouve le Pluton de New Ross et la suite Intrusive Polgphasee de Big Indian, sous-jacents à une portion des régions centrale et orlentale du Batholite de South Mountain $\left(10,000 \mathrm{~km}^{2}\right)$, ains1 que les plutons de Sangster Lake et de Larrys River à l'extremite orientale de la Zone de Meguma.

A i'alde surtout du rapport eU/eTH, on montre comment ces donnèes peuvent circonscrire les diverses unitès granitiques englobant ces gros plutons et batholites. Les sites montrant le rapport signal: bruit le plus élevé se correlent directement avec la présence de petits intrusifs leucogranitiques à deux micas. A 1 'opposé, le rapport le plus bas s'observe dans les réglons formées d'unités monzogranitiques riches en biotite. La concentration des éléments en traces, tels $\mathrm{U}, \mathrm{Th}, \mathrm{Rb}, \mathrm{Sr}, \mathrm{Zr}$ et $\mathrm{T} 1$, au sein de ces diverses unites confirme ces observations et indique que la varlation en eU/eTh pourrait résulter du degre de differenciation magmatique.

Les cas représentatifs decrits dans cet article montrent auss 1 que des facteurs autres que la composition du substratum peuvent influencer le relevé radiométrique aeroporté d'une région donnee. Par exemple, certains paramétres tels que le type et le style de la minéralisation, le type et le degre d'interaction des fluides alnsi que la provenance et l'epalsseur des depots de t111 peuvent aussi jouer un rôle cumulatif majeur dans la détermination de la signature spectrometrique aeroporté au-dessus d'une région. Par consequent, on doit tenir compte de ces variables lors de toute investigation geologique ou campagne d'exploration.

[Tradu1t par le journal]

\section{INTRODUCTION}

The Meguma Zone (MZ) of Nova Scotia consists of a sequence of Lower Paleozolc metasedimentary rocks which were intruded during Devono-Carboniferous time by a number of peraluminous granitolds. The granitold rocks, in particular the South Mountain Batholith (SMB), were the focus of intense mineral exploration during the mid-late 1970s which resulted in the discovery of significant granophile element mineralization. The most important discoveries were the greisen-hosted East Kemptville tin-base metal deposit (Richardson et al., 1982) and the vein-type Millet Brook uranium deposit (Chatterjee et al., 1985).

The Geological Survey of Canada has aided exploration activity by systematically collecting high sensitivity gamma-ray spectrometric data in Nova Scotia since 1976. It was intended that the surveys would prove useful in: 1 . reglonal identification and delineation of variants within the granitold rocks; and 2 . outlining areas with potential granophile element "specialization" and assoclated mineralization. The general principles 
of gamma-ray surveying, including instrumentation, electronics and operational procedures are given elsewhere (Bristow, 1979; Grasty, 1979; Killeen. 1979).

The surge of mineral exploration in the MZ granitold rocks has been accompanied by detalled geological investigations of these same rocks by government agencles and universities (summarized in Clarke and Muecke, 1985). In addition, several studies have correlated the airborne gamma-ray data with highly evolved units, pervasive autometasomatic alteration, and granophile element mineralization (Chatterjee and Muecke, 1982; Ford and Ballantyne, 1983; 0'Re111y, 1985; Ford and O'Re111y, 1985). However, recent detalled mapping of the SMB allows an opportunity to evaluate alrborne gamma-ray surveys as a mapping and exploration tool. The previous studies left many areas unexplained due to insufficient bedrock mapping support. Thus, the purpose of this paper is to 1llustrate the viability of airborne gammaray spectrometry for bedrock mapping and mineral exploration. For this purpose the discussion will focus mainly on three selected areas of granitic rocks in the $\mathrm{MZ}$ for which detalled mapping results and geochemical data are avallable. This control allows for consideration of factors such as compositional variability of bedrock, pervasive metasomatic and hydrothermal alteration effects, type and style of mineralization, amount of bedrock exposure, and type of overburden cover.

\section{REGIONAL GEOLOGY}

The term Meguma Zone was first used by Williams (1978) to describe mainland Nova Scotia south of the Cobequid-Chedabucto Fault Zone (Fig. 1). This area consists of a thick sequence of Cambrian to Ear1y Devonian metasedimentary and metavolcanic rocks intruded by a suite of Devono-Carboniferous, peraluminous granitold rocks. These rocks form a basement for sedimentary rocks of Carboniferous and Trlassic age. Most of the metasedimentary rocks belong to a thick turbidite sequence known as the Meguma Group, consisting of the Goldenville Formation (metawacke and quartzite) and conformably overlying Halifax Formation (slate and schist) (Taylor, 1969; Schenk, 1971). These rocks were jeformed into upright, northeast-trending folds during the Acadian Orogeny (Fyson, 1966). The middle-late stages of this orogeny were accompanied by greenschist-amphibolite facies regional. metamorphism (Keppie and Muecke, 1979).

Approximately forty percent of the $\mathrm{MZ}$ is underlain by peraluminous granitojd rocks. The largest massif occupies $10,000 \mathrm{~km}$ and has been named the South Mountain Batholith (SMB; McKenzie and Clarke, 1975). A number of similar, but smaller granitold plutons occur throughout the rest of the MZ (Fig. 1). The granitold units have, in most areas, post-tectonically intruded the metasedimentary rocks and range in composition from tonalite to leucogranite. Blotite monzogranite and granodiorite comprise the majority of present day exposure.

Clarke and Muecke (1985) summarlzed the petrological and geochemical data from a number of studies of $M Z$ granitoid rocks. In addition, a paraintrusive suite of rocks developed as a result of interaction of a fluid phase with either residual magma or previously crystallized rock, or both (Muecke and Clarke, 1981; Chatterjee and Muecke, 1982). The fluid interaction caused enrichment in granophile elements such as $\mathrm{Sn}$, U, $\mathrm{Rb}, \mathrm{L} 1, \mathrm{~F}, \mathrm{~B}$ and $\mathrm{Cs}$ and formed sericitized granite, albitized granite, albitite and various greisens. The para-intrusive or "specialized" suites volumetrically represent only a small portion of the granitold rocks. Their close spatial and genetic association with significant Sn-U mineralization and areas of pervasive metasomatism and hydrothermal alteration has been documented (Chatterjee and Muecke, 1982; Richardson et al., 1982; 0'Re111y et al., 1985; Kontak, 1987).

Radiometric age determinations from the various granttold units commonly fall in the range of $370 \pm 5$ Ma (Clarke and Halliday, 1980; Reynolds et al., 1981). Samples from the para-intrusive sultes commonly yield apparent ages in the 260-340 Ma Interval (Reynolds et al., 1981; Chatterjee, 1983; Zent1111 and Reynolds, 1985; 0'Re111y et al., 1985). This time discrepency is not fully understood, but may have resulted from elther a Permo-Carboniferous magmatic event or Hercynian tectonothermal overprinting of the $\mathrm{MZ}$, or both (Reynolds et al., 1981; Reynolds et al., 1987).

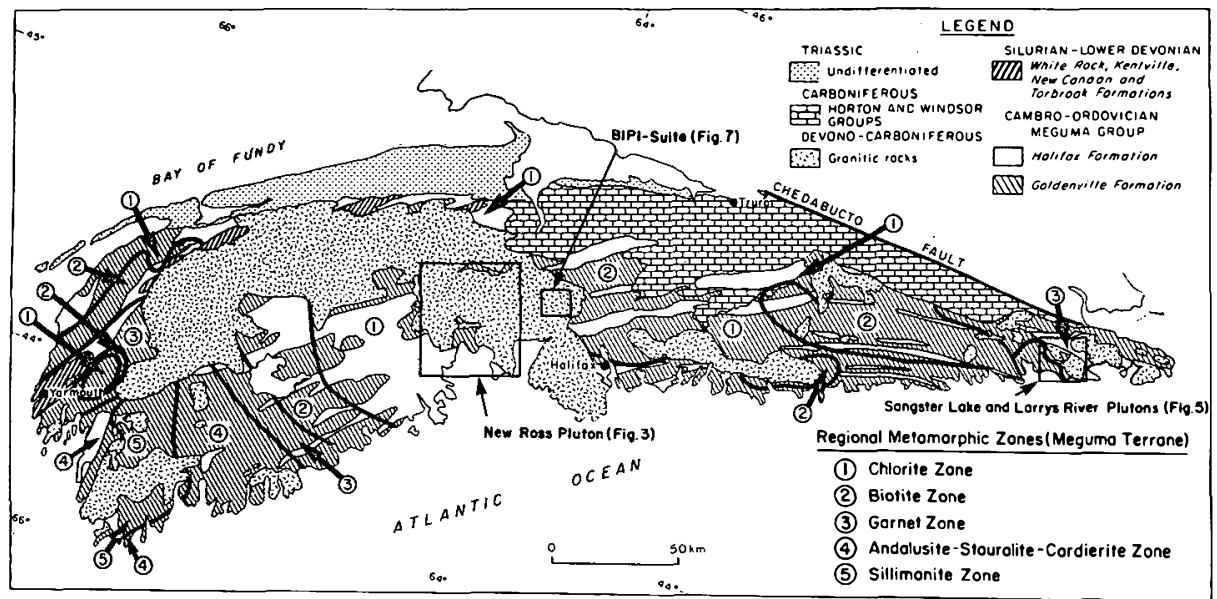

Fig. 1. Geology of the Meguma Zone showing the locations of case study areas discussed in this paper. 


\section{AIRBORNE GAMMA-RAY SPECTROMETRIC SURVEYS}

This study utilizes the results of airborne gamma-ray spectrometric surveys flown over the $M Z$ by the Geological Survey of Canada from 1976 to 1986. Two of the selected case study areas, the New Ross P1uton and the Sangster Lake-Larrys River plutons, have alrborne surveys at a $1 \mathrm{~km}$ line spacing (Fig. 1). A third study area, the Big Indian Polyphase Intrusive suite is covered by a survey flown at a $250 \mathrm{~m}$ line spacing. The data were acquired with 50 1itres of $\mathrm{NaI}$ crystal detectors at a mean terrain clearance of 125 metres. The surveys report responses as total count (TC), equivalent uranium (eU), equivalent thorium ( $\mathrm{eTh}$ ), potassium $(\mathrm{K})$ and their various ratios.

The data delineate many areas of anomalous radioelement content, most of which are associated with granitic rocks (Ford, 1982; Fig. 2). An examination of the data distinguishes different plutons from each other as we 11 as varlous areas within individual granites based on radioelement responses. Ford (1982) was able to define separate radioelement trends, such as elevated eU, elevated eTh, elevated eU on constant eTh, elevated eU on decreasing $e T h$ and areas of increasing $e U$ and $e T h$.

Follow-up investigations to the airborne surveys involving in-situ gamma-ray spectrometry and reconnaissance 11thogeochemistry have confirmed that the radioelement variations within the granitoid rocks correspond with those indicated by the airborne data (Ford, 1982; Ford and Ballantyne, 1983). Airborne radioelement concentrations are generally less than true bedrock values due to some combination of shielding effects of overburden, wetness and vegetation cover. These factors must be considered in evaluation of each particular survey area but studies have shown that, although the responses are lessened, the relative proportions of uranium and thorium in the airborne data are reasonable estimates of the bedrock concentrations (Charbonneau et al., 1976).

This study utilizes, for the most part, comparisons of the eU/eTh ratio with geology and geochemistry for the selected case study areas. This was done for two main reasons: firstly, for simplicity of presentation, and secondly, the eU/eTh ratio encompasses both eU and eTh variation and these elements display the most prevalent correlations.

\section{CASE STUDY AREAS}

The airborne gamma-ray spectrometric data collected over the MZ shows increasing radioelement response associated with the granitold rocks (Fig. 2 ). Three case study areas have been selected from which there is sufficient detailed geological mapping and geochemical results to warrant a comparison of geological relations and radiometric response. These are: (1) the New Ross Pluton (NRP) in the central portion of the SMB between New Ross and the Mahone Bay-St. Marys Bay area; (2) the Sangster Lake (SLP) and Larrys River (LRP) Plutons located in the eastern region of the $M Z$; and (3) the Big Indian Polyphase Intrusive suite (BIPI suite) in the northeastern portion of the SMB (Fig. 1).

THE NEW ROSS PLUTON

\section{Geology}

The NRP is a roughly circular body (in plan view) which has intruded graniodiorite and biotite monzogranite of the SMB. It is comprised of four distinct granitic units based on texture, mineralogy and contact relations (Fig. 3a; MacDonald et al., 1987a). The first unit is 1ight grey, fine- to coarse-grained, muscovite-biotite monzogranite. This monzogranite varies texturally from megacrystic (up to $10 \% \mathrm{~K}$-feldspar megacrysts) at its center to seriate and equigranular toward its margins. The second unit is a buff-orange, medium- to coarse-grained, moderately equigranular to megacrystic, biotite-muscovite leucomonzogranite. The buff-orange colour and common appearance of dark red cores of $\mathrm{K}$-feldspar megacrysts are characteristic of this unit. These features are attributed to pervasive deuteric hematitization. The third unit is fine- to mediumgrained, texturally variable leucomonzogranite. Compositionally this unit is similar to unit 2 , but

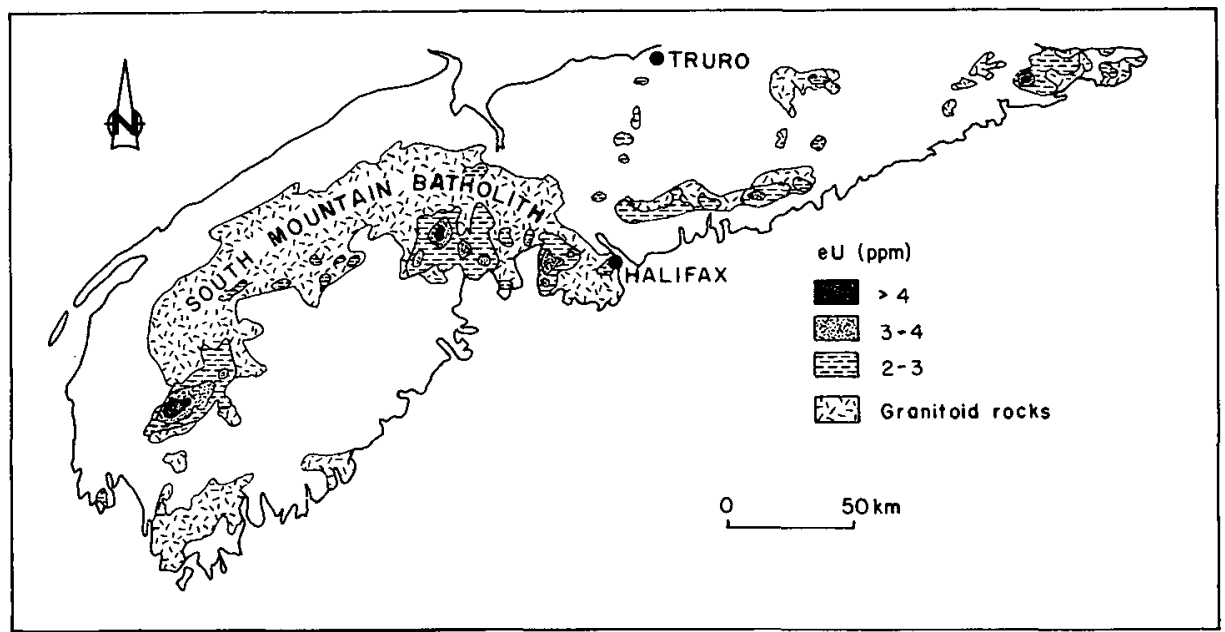

Fig. 2. Equivalent uranium distribution patterns over the Meguma Zone. Compiled from airborne spectrometric surveys flown by the Geological Survey of Canada between 1976-1982. 
occurrences of both fracture-controlled and pervasive metasomatic-hydrothermal alteration were frequent1y noted (Corey, j.n preparation). The alteration is interpreted to be due to late- or post-magmatic interaction with a fluid phase. Such alteration is described by Chatterjee and Muecke (1982) for formation of the para-intrusive suite of rocks within the SMB.

The common occurrence of the third unit within embayments or protuberances of unit 2 suggests that these small bodies may represent hydrothermally altered textural equivalents of unit 2 rather than highly differentiated intrusive rocks. Contact relationships between rocks of units 3 and 2 are enigmatic with the same body commonly exhibiting both sharp and gradational contacts. Charest (1976) reached a similar conclusion for porphyry bodies in the New Ross area in the northern region of the NRP.

A fourth unit consists of fine-to mediumgrained, texturally variable (saccharoldal, equigranular, porphyritic) leucogranites $(<2 \%$ biotite) and syenogranites (Streckeisen, 1976) which have sharp intrusive contacts with their surrounding rocks. Unit 4 rocks have similar mineralogy, texture and styles of hydrothermal alteration as those of unit 3 , but differ in that unit 4 occur as separate, discrete intrusions whereas unit 3 occurs as gradational, alteration facies within embayments and protuberances of unit 2. Field relations and trace element levels indicate that unit 4 rocks are late-stage and highly-evolved (MacDonald et al., 1987a; 1988).

The NRP hosts numerous polymetalilc mineral occurrences which have been studied by several investigators (Fig. 3; Charest, 1976; Farley, 1978; Palmer, 1980; 0'Re111y et al., 1982; Logothet1s, 1984; MacDonald et al., 1987a, b). Examples of the varlous types and styles of mineralization found in the NRP are given in Table 1 with locations indicated in Figure $3 a$.

\section{Airborne Spectrometric Response}

The equivalent uranium/equivalent thorium (eU/eTh) distribution pattern for the NRP is complex and variable over the area (Fig. 3b). Airborne ratios on a regional scale consist of a large central area of low ratio response $(<0.4)$ flanked on two sides by large areas of elevated ratio response $(>0.4)$ which in turn contain numerous small anomalies of greater response $(>1.2)$. Ford and 0'Reilly (1985) confirmed the airborne spectrometric measurements with several in-situ gamma-ray spectrometric reconnaissance surveys.

\section{Comparison of Spectrometric Response} with Geology

A comparison of the geology and eU/eTh distribution pattern shows that the eU/eTh response correlates well with bedrock (Figs. 3a, b). A central long narrow corridor of low ratio values $(<0.4)$ is underlain predominantly by rocks of unit 1 intruded by a very coarse-grained, megacrystic (20-40\%) variety of unit 2 . The broad anomalous area $(0.4->1.2)$ flanking the corridor of low response corresponds with leucomonzogranite and similar rocks of units 2,3 and 4 . Highest responses within this area correlate directly with occurrences of units 3 and 4 .

Elevated eU/eTh responses in areas of 11ttle outcrop exposure (southeast of New Ross, Fig. 3b) can also be correlated with local geology. Pebble counts of till samples from these areas show that the till consists of close to $100 \%$ fine-grained leucomonzogranite (M. Graves and P. Finck, personal communication). This strongly suggests that these areas are underlain by subcropping leucomonzogranite and that the elevated ratio expression is simply a reflection of till comprised predominantly of this 1ithology.

There is a close association of elevated eU/eTh with many of the mineral occurrences present in the NRP. The majority of the occurrences fall within or in close proximity to $(<0.5 \mathrm{~km})$ high ratio anomalies ( $>1.2$; Fig. $3 \mathrm{~b})$. Also of note is an association of the occurrences and anomalies with late-stage differentiates and/or areas of pervasive hydrothermal alteration (Table 1).

However, a closer look reveals that several ambiguities exist. Most obvious is that not all mineral occurrences are coincident with elevated eU/eTh response. There are several significant mineral occurrences in areas of lower ratio response $(<0.8$; e.g., Nos. $21,22,23$; Table 1$)$ and also those with no perceptable signature (Nos. 26, 28b). Horne (1987) found these latter occurrences to be hosted by biotite monzogranite (unit 1) which characteristically has low eU/eTh, thereby providing a 1ikely explanation.

The former occurrences are hosted by rocks of Units 3 and 4 and, therefore, would be expected to have the comparable high ratio expression exhibited by these units elsewhere within the NRP. The explanation for this contradiction presents another variable to consider when evaluating airborne spectrometric surveys. A large portion of the northern area of the NRP is covered by a thick $(>10$ m), clay-rich and far-travelled glacial till (Lawrencetown Ti11, Fig. 3b; Graves and Finck, in preparation; Finck and Graves, in preparation). The remainder of the NRP is covered by locally derived glacial deposits. Thick overburden significantly shields the spectrometric response of bedrock (Charbonneau et al., 1976). Limited geochemical data avallable from the area of Lawrencetown T111 cover (Fig. 3b; L.J. Ham, unpublished data) indicates that much of this area is underlain by granite of elevated $U / T h$ ratio $(>1)$. It is therefore possible that the low ratio response is due to a shielding effect by the Lawrencetown Till. It is interesting to note that adjacent areas of elevated response coincide with areas of thin till cover.

The style of mineralization also appears to have an affect upon the eU/eTh ratio. This is 11lustrated by those occurrences which show no genetic relationship with their host (Nos. 5, 8, 10; Table 1). These showings are examples of fracture-controlled, vein-type mineralization which have anomalous ratio response hosted in rocks of units 1 and 2 . These occurrences are associated with intense, widespread and pervasive hydrothermal alteration of the host rocks. 0'Reilly (1985) has described an increase of $U$ and $U / T h$ ratio assoclated with progressive hydrothermal alteration within monzogranite of the Sangster Lake Pluton. The concept of intense alteration processes giving 

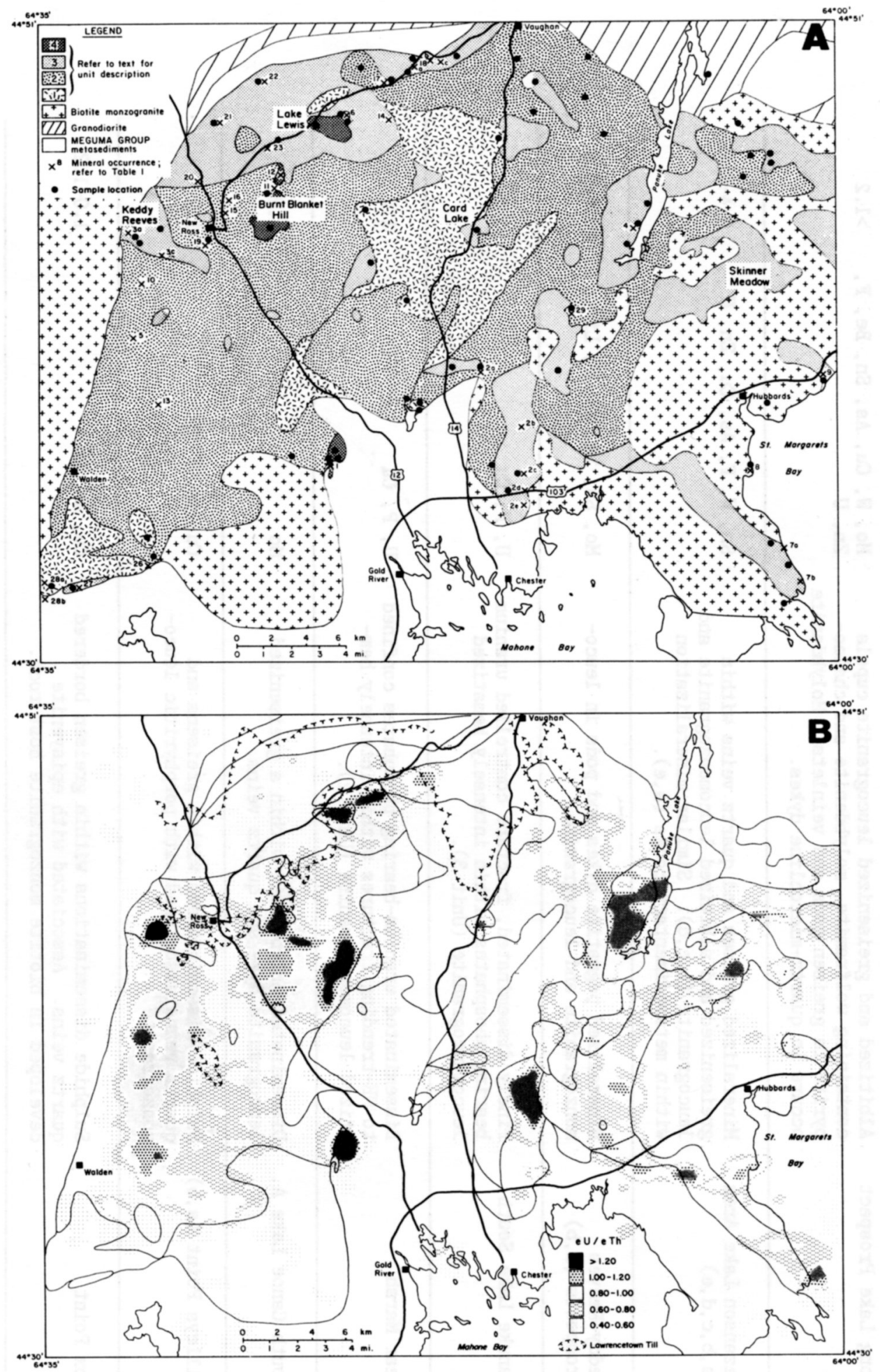

Fig. 3. Geology map (A) and corresponding eU/eTh pattern map (B) of the New Ross Pluton. See Figure 1 for location. Note: multiple samples were collected at several sample sites.

rise to elevated radioelement content is further discussed in the following sections dealing with the Sangster Lake Pluton. Quite possibly, a similar process has resulted in the observed ratio anomalles in host rocks that would otherwise have flat or background levels.
Within the NRP there are a number of high ratio anomalies which are not associated with known granophile mineralization (Skinner Meadow, Card Lake, Burnt Blanket H111; Figs. 3a, b), although the absence of mineralization may be due to lack of exposure or recognition during mapping. Corey (in 
Table 1. Description of mineral deposits of the New Ross Pluton and corresponding eU/eTH response. Locations according to number are shown on Figure 3.

\begin{tabular}{|c|c|c|c|c|}
\hline No. & Name & Type and Style of Mineralization & Association & $\begin{array}{l}\text { eU/eTh } \\
\text { Host Rock }\end{array}$ \\
\hline 1. & Long Lake Prospect & $\begin{array}{l}\text { Albitized and greisenized leucogranite cupola } \\
\text { containing wolframite, molybdenite and chalco- } \\
\text { pyrite in greisen pods and veinlets. Molybdenite } \\
\text { occurs in quartz-microcline dykes. }\end{array}$ & $\begin{array}{l}\text { Mo, W, Cu, As, Sn, Be, F, } \\
\mathrm{Zn}, \mathrm{U}\end{array}$ & $>1.2$ \\
\hline 2. & $\begin{array}{l}\text { Bezanson Lake Area } \\
(a, b, c, d, e)\end{array}$ & $\begin{array}{l}\text { Mineralized greisen and quartz veins within } \\
\text { greisenized and albitized leucomonzogranite and } \\
\text { leucogranite }(b, c, d) \text {. Similar mineralization } \\
\text { within metasedimentary rocks }(a, e) \text {. }\end{array}$ & $\mathrm{Sn}, W, F, A s, C u, Z n, U$ & $0.4-1.2$ \\
\hline 3. & $\begin{array}{l}\text { Keddy-Reeves } \\
\text { Prospects }(a, b)\end{array}$ & $\begin{array}{l}\text { Mineralized pegmatite dykes and pods in leuco- } \\
\text { monzogranite and leucogranite. }\end{array}$ & Mo, Sn, Ta, Nb, F, L1 & $0.6-1.0$ \\
\hline & Panuke Lake South & $\begin{array}{l}\text { Finely disseminated, fracture controlled uranium- } \\
\text { bearing phosphates within intensely hematized } \\
\text { leucomonzogranite (Unit } 3 \text { ). }\end{array}$ & $\mathrm{U}, \mathrm{P}, \mathrm{Cu}$ & 1.2 \\
\hline & Bear Marsh & $\begin{array}{l}\text { Disseminated uranium-bearing phosphates confined } \\
\text { to NE-trending fractures within intensely hem- } \\
\text { atized leucomonzogranite (Unit 2). }\end{array}$ & $\mathrm{U}, \mathrm{P}, \mathrm{Cu}$ & 1.2 \\
\hline & South Canoe Lake A. & $\begin{array}{l}\text { Disseminated molybdenite within a greisenized } \\
\text { leucogranite dyke and quartz veins. }\end{array}$ & Mo & 1.2 \\
\hline 7. & Tilleys Point $(a, b)$ & $\begin{array}{l}\text { Sulphide disseminations within greisens and } \\
\text { quartz veins assoclated with porphyritic leuco- } \\
\text { monzogranite. }\end{array}$ & $\mathrm{Cu}, \mathrm{As}, \mathrm{F}$ & 1.2 \\
\hline & Fox Point & $\begin{array}{l}\text { Sulphide disseminations within greisen bordered } \\
\text { quartz veins. Associated with episyenite } \\
\text { developed in biotite monzogranite host rock. }\end{array}$ & $\mathrm{Cu}, \mathrm{As}, \mathrm{Zn}$ & $1.0-1.2$ \\
\hline & The Puddle & $\begin{array}{l}\text { Disseminated cassiterite and arsenopyrite in } \\
\text { quartz velns hosted by hematized leucomonzo- } \\
\text { granite (Unit } 3 \text { ). }\end{array}$ & $\mathrm{Sn}, \mathrm{Pb}, \mathrm{As}$ & $0.6-0.8$ \\
\hline 10. & Haddock Lake & (See Bear Marsh) & $\mathrm{U}, \mathrm{P}, \mathrm{Cu}$ & $0.8-1.0$ \\
\hline
\end{tabular}


Table 1. Description of mineral deposits of the New Ross Pluton and corresponding eU/eTH response. Locations according to number are shown on Figure 3.

\begin{tabular}{|c|c|c|c|c|}
\hline No. & Name & Type and Style of Mineralization & Association & $\begin{array}{l}\text { eU/eTh } \\
\text { Host Rock }\end{array}$ \\
\hline 11. & Leville Road & $\begin{array}{l}\text { Wolframite and chalcopyrite disseminated in peg- } \\
\text { matite pods and the host porphyritic leucogranite. }\end{array}$ & W. $\mathrm{Cu}$ & $0.6-0.8$ \\
\hline 12. & Round Lake & $\begin{array}{l}\text { Wolframite disseminated within greisenized leuco- } \\
\text { granite. }\end{array}$ & W & $0.6-0.8$ \\
\hline 13. & Nevertell Lake & $\begin{array}{l}\text { Cassiterite and wolframite in pegmatite hosted by } \\
\text { leucomonzogranite (Unit 2). }\end{array}$ & $\mathrm{Sn}, \mathrm{W}$ & $0.6-0.8$ \\
\hline 14. & South Canoe Lake B. & $\begin{array}{l}\text { Molybdenite and fluorite in pegmatite associated } \\
\text { with porphyritic leucogranite. }\end{array}$ & Mo. $F$ & $0.6-0.8$ \\
\hline 15. & Morleys Pegmatite & $\begin{array}{l}\text { Cassiterite, wolframite, fluorite and chalco- } \\
\text { pyrite in pegmatite hosted by leucomonzogranite. } \\
\text { Jasper breccia dyke in intensely hematized leuco- } \\
\text { monzogranite (Unit 2). }\end{array}$ & $\begin{array}{l}\mathrm{Sn}, W, F, \mathrm{Cu}, \mathrm{U} \\
W, \mathrm{Cu}, \mathrm{F}\end{array}$ & $0.6-0.8$ \\
\hline 16. & M111 Brook & $\begin{array}{l}\text { Lepidolite and fluorite in pegmatite dyke hosted } \\
\text { by leucomonzogranite (Unit 2). }\end{array}$ & L1, F & $0.4-0.6$ \\
\hline 17. & Canoe Lake & $\begin{array}{l}\text { Fluorite occurs as fracture fillings in intensely } \\
\text { altered leucomonzogranite (Unit. 2) and leuco- } \\
\text { granite dykes. }\end{array}$ & $\mathbf{F}$ & $0.6-0.8$ \\
\hline 18. & $\begin{array}{l}\text { Leminster Area } \\
(a, b, c)\end{array}$ & $\begin{array}{l}\text { Molybdenite and fluorite occurs as dessiminations } \\
\text { and fracture fillings in pegmatite pods, quartz } \\
\text { veins and greisenized leucomonzogranite (Unit } 3 \text {; } \\
\text { a,c) and within leucomonzogranite dykes in Meguma } \\
\text { metasedimentary rocks (b). }\end{array}$ & Mo, $F$ & $0.2-0.6$ \\
\hline 19. & Lake Darling & $\begin{array}{l}\text { Chalcopyrite and molybdenite disseminations occur } \\
\text { in pegmatite and greisen selvage within leuco- } \\
\text { monzogranite (Unit } 2 \text { ). }\end{array}$ & $\mathrm{Cu}, \mathrm{Mo}, \mathrm{F}$ & $0.4-0.6$ \\
\hline 20. & Harriston & $\begin{array}{l}\text { Uranium-bearing phosphates occur in hematized } \\
\text { fractures within leucomonzogranite (Unit } 3 \text { ). }\end{array}$ & $\mathrm{U}, \mathrm{P}$ & $0.4-0.6$ \\
\hline
\end{tabular}


Table 1. Description of mineral deposits of the New Ross Pluton and corresponding eU/eTH response. Locations according to number are shown on Figure 3 .

\begin{tabular}{|c|c|c|c|c|}
\hline No. & Name & Type and Style of Mineralization & Association & $\begin{array}{l}\text { eU/eTh } \\
\text { Host Rock }\end{array}$ \\
\hline 21. & Turner Tin & $\begin{array}{l}\text { Cassiterite, chalcopyrite, sphalerite, wolframite } \\
\text { fluorite and uranium-bearing phosphate in quartz } \\
\text { and quartz greisen veins in leucomonzogranite } \\
\text { (Unit 2) and a quartz porphyry dyke. }\end{array}$ & $\mathrm{Sn}, \mathrm{Cu}, \mathrm{Zn}, \mathrm{W}, \mathrm{F}, \mathrm{U}$ & $0.4-0.6$ \\
\hline 22. & $\begin{array}{l}\text { Wallaback Lake } \\
\text { (Grassy Brook) }\end{array}$ & $\begin{array}{l}\text { Cassiterite and sphalerite disseminations in } \\
\text { greisen patches in a pegmatite and leucogranite } \\
\text { plug in leucomonzogranite (Unit 3). }\end{array}$ & $\mathrm{Sn}, \mathrm{Zn}, \mathrm{L} 1, \mathrm{~F}$ & $0.4-0.6$ \\
\hline 23. & Walker Moly & $\begin{array}{l}\text { Molybdenite, chalcopyrite, cassiterite, wolfram- } \\
\text { 1te and fluorite in pegmatite and greisen selvage } \\
\text { within a leucogranite-pegmatite plug intruded } \\
\text { into leucomonzogranite (Unit } 2 \text { ). }\end{array}$ & Mo, $\mathrm{Cu}, \mathrm{F}, \mathrm{Sn}, \mathrm{W}$ & $0.4-0.6$ \\
\hline 24. & Nine Mile Lake & $\begin{array}{l}\text { Molybdenite disseminated in quartz greisen vein } \\
\text { In leucomonzogranite (Unit } 3 \text { ). }\end{array}$ & Mo & $0.4-0.6$ \\
\hline 25. & Timber Lake & $\begin{array}{l}\text { Fluorite occurs as fracture fillings in pegma- } \\
\text { tite, quartz greisen and leucomonzogranite } \\
\text { (Unit } 3 \text { ). }\end{array}$ & $\mathbf{F}$ & $0.4-0.6$ \\
\hline 26. & Millet Lake & $\begin{array}{l}\text { Chalcopyrite and fluorite along fractures and } \\
\text { quartz greisen veins in monzogranite (Unit 1). }\end{array}$ & $\mathrm{Cu}, \mathrm{F}$ & $<0.4$ \\
\hline 27. & Whale Lake & $\begin{array}{l}\text { Wolframite, chalcopyrite and molybdenite in } \\
\text { quartz greisen veins in biotite monzogranite } \\
\text { (Unit 1). }\end{array}$ & w, Cu, Mo & $<0.4$ \\
\hline 28. & Caribou Lake & Chalcopyrite and molybdenite in syenogranite. & $\mathrm{Cu}, \mathrm{Mo}$ & $<0.4$ \\
\hline 29. & $\begin{array}{l}\text { Upper New Cornwall } \\
(a, b)\end{array}$ & $\begin{array}{l}\text { Arsenopyrite, chalcopyrite, sphalerite and wolf- } \\
\text { ramite in albitites (a) and quartz greisen veins } \\
\text { and pods (b) within biotite monzogranite (Unit 1). }\end{array}$ & As, $\mathrm{Cu}, \mathrm{Zn}, \mathrm{W}$ & $<0.4$ \\
\hline
\end{tabular}


preparation) has revealed the presence of intense, pervasive hydrothermal alteration within these areas implying that the high ratio anomaly is a function, and hence indicator, of these effects. The high ratio anomaly immediately east of Skinner Meadow, for example, is underlain by an area of intense and pervasive metasomatism of unit 3 rocks containing discrete pods and dykes of episyenite (Corey, in preparation).

\section{Lithogeochemical Comparison}

Geochemical results from samples of the various units of the NRP provide further verification of the observed trends in the spectrometric surveys. For example, in Figure 4 a trend of increasing $U$ and decreasing Th from units 1 to 4 is observed. Further evidence of progressive differentiation is provided by covariation of $\mathrm{Th} / \mathrm{U}$ with $\mathrm{Ti}$ and $\mathrm{Zr}$ (plots not shown here) and $\mathrm{Rb} / \mathrm{Sr}$ with $\mathrm{U}$ and $\mathrm{Th}$ (also not shown).

These data include rocks of the para-intrusive suite (greisens and some fine-grained rocks) as defined by Chatterjee and Muecke (1982). Rocks of this suite are the result of crystalqmelt-fluid interaction and hence may have elemental trends which vary from expected magmatic trends. The para-intrusive suite of rocks in the NRP are the most evolved and exhibit the most geochemical scatter as a result of fluid:rock interaction (Fig. 4). This latter process invariably involves a volatile-charged fluid phase enriched in granophile elements.

Several seemingly highly evolved unit 4 rocks (e.g. , Keddy-Reeves and Lake Lewis Leucogranites; Fig. 3a) have both low $U$ and low Th contents, thus contrasting with other leucocratic rocks which commonly display increasing $U$ with decreasing Th (Fig. 4). Chatterjee et al. (1985) proposed that the depletion of $U$ within leucogranites from the the Lake Lewis area reflects hydrothermal leaching of $U$ in the endocontact roof zone of the intrusion. Conceivably, such a process may also account for other U-depleted rocks indentified in this study. Increasing $\mathrm{Rb} / \mathrm{Sr}$ versus $\mathrm{U}$ implies that even though these rocks have lower $\mathrm{U}$, their high $\mathrm{Rb} / \mathrm{Sr}$ infers that they correspond to a highly evolved stage.

\section{SANGSTER LAKE AND LARRYS RIVER PLUTONS}

\section{Geology}

The Sangster Lake (SLP; $24 \mathrm{~km}^{2}$ ) and Larrys River (LRP; $36 \mathrm{~km}^{2}$ ) plutons have intruded Meguma Group metasedimentary rocks in the eastern extremity of the MZ (Fig. 1). The SLP has anomalous airborne spectrometric response for eU and the eU/eTh ratio (F1g. 2) which was the focus of several petrological and geochemical investigations (Ford and Ballantyne, 1983; 0'Re111y, 1984; 1985).

Both plutons consist predominantly of texturally distinct and gradational varieties of monzogranite into which were emplaced small leucomonzograniteleucogranite intrusions ( $\mathrm{F} 1 \mathrm{~g} . \mathrm{5}$ ). The homogeneous, two-mica monzogranite comprising the SLP displays an increase of post-crystallization alteration effects in the central and eastern region of the pluton (0'Re111y, 1984). Secondary albitization of plagioclase, muscovitization of albite and $\mathrm{K}-$ feldspar and the formation of secondary apatite,

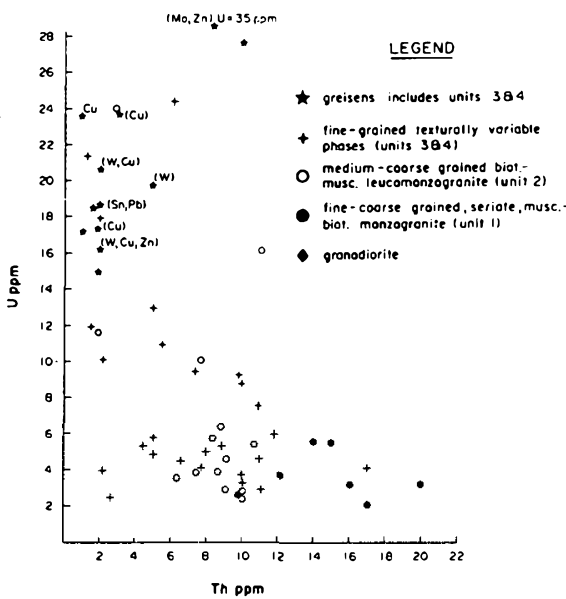

Fig. 4. P1ot of $U$ versus Th data from the various rock types of the New Ross Pluton. Sample locations are shown in Figure 3.

chlorine-bearing apatite and uranium-bearing $\mathrm{Fe}$ phosphate were cited by Ford and 0'Re111y (1985) as indicative of interaction of the previously crystallized granitic rocks with a volatile-charged fluid phase.

\section{Airborne Spectrometric Response}

The eU/eTh distribution pattern for the SLP and LRP shows the LRP exhibits a uniformly low response for eU/eTh $(<1.0)$ whereas the SLP has a highly varlable ratio response (Fig. 5). The western end of the SLP has a background response $(<1.0)$ whereas the central and eastern region is quite anomalous (approximate1y 2.5).

Ford and Ballantyne (1983) have confirmed the airborne survey results by several in-situ gammaray spectrometer traverses over the plutons. Overburden cover over much of the plutons is absent to very thin. Where surficial deposits do occur they are dominated by boulder fields consisting of locally derived granite. These factors suggest that overburden shielding effects in this study area had little or no consequence on the radioelement distribution patterns.

\section{Comparison of Spectrometric Response with Geology}

0'Reilly (1984) found that, within the SLP, there is a definite correlation of increasing levels of $\mathrm{eU}$ and the eU/eTh ratio with higher degrees of post-crystallization hydrothermal alteration. Ford and Ballantyne (1983) 1dentified chlorine-bearing apatite and uranium-bearing $\mathrm{Fe}$-phosphate as the mineral species accommodating the increased uranium in these rocks. Ford and O'Reilly (1985) determined that these phases accompanied the advanced stages of the pervasive alteration which affected these rocks.

By contrast, the monzogranitic units of the LRP and the western end of the SLP have typical magmatic textures. These areas are characterized by having background or average radioelement levels in the airborne spectrometric data.

The area of the SLP showing increased hydrothermal alteration and anomalous spectrometric 


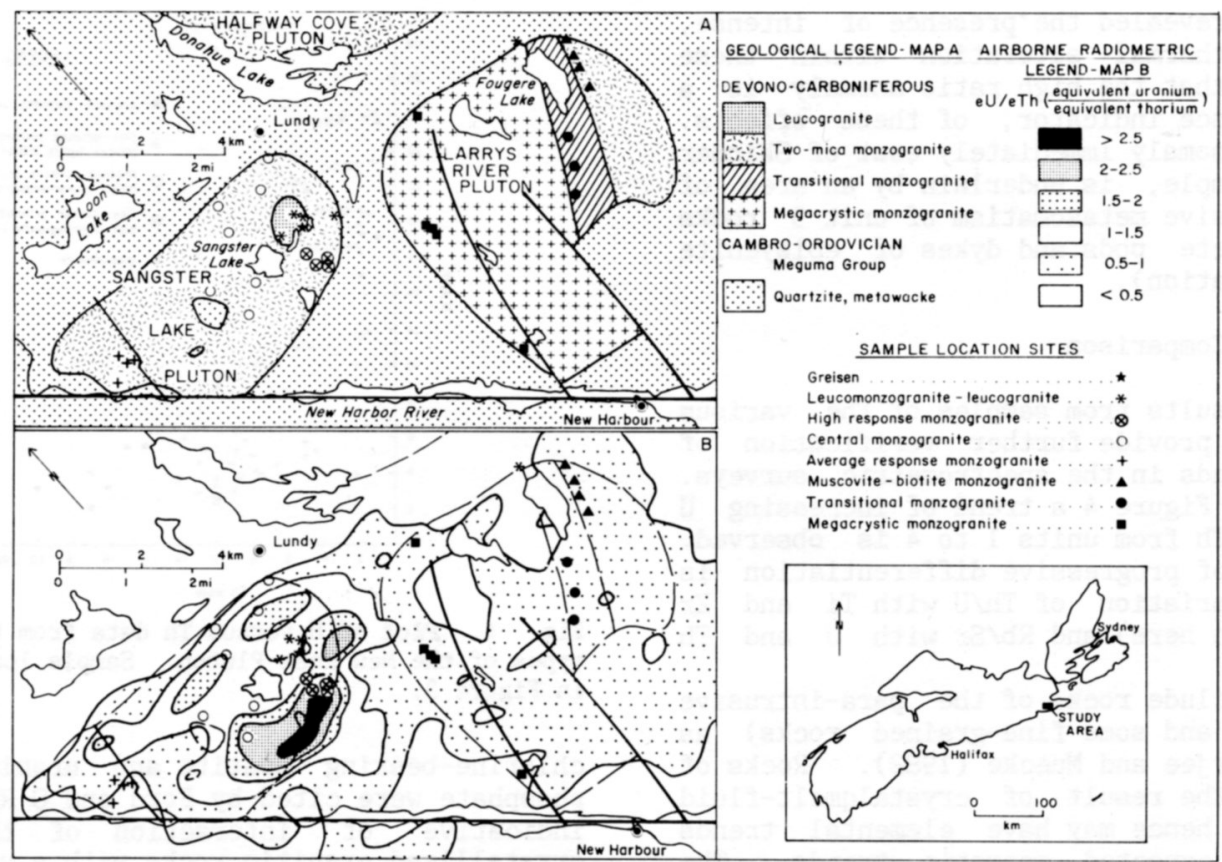

Fig. 5. Geology map (A) and corresponding eU/eTh pattern map (B) for the Sangster Lake and Larrys River Plutons. See Figure 1 for location.

response 11kely represents exposure of the uppermost roof zone of the pluton (0'Reilly, 1985). Pollard (1983) summarized a large number of studies of mineralized granites which stress the importance of the apical regions of granitic plutons for the localization of magmatically derived, granophile element-enriched hydrothermal fluids. Such fluids commonly result in pervasive hydrothermal alteration of large volumes of previously crystallized rocks. This model is invoked for the origin of the features observed within the SLP and hence the airborne surveys in this instance have efficiently recognized an area of widespread pervasive hydrothermal alteration.

\section{Lithogeochemical Comparison}

O'Reilly (1985) subdivided the LRP and SLP according to rock type and spectrometric response category in order to examine the geochemistry relative to the airborne spectrometric response (Fig. 5). A plot of $U$ versus Th (Fig. 6) verifles the airborne spectrometric results. The monzogranites of the LRP and the region of the SLP of average radiometric response show a decrease of Th corresponding with a slight decrease of U. By contrast, the hydrothermally altered monzogranites of the SLP (central and high response monzogranite) and the leucomonzogranites have markedly higher levels of $U$ and lower levels of Th. Ford and O'Re111y (1985) also determined a covarlation of granophile elements with $U$ and $U / T h$ (plots not given here). In addition, the hydrothermally altered rocks have decreased levels of $\mathrm{Sr}, \mathrm{Ba}$ and $\mathrm{Pb}$ which is consistent with the breakdown of primary feldspars during alteration.

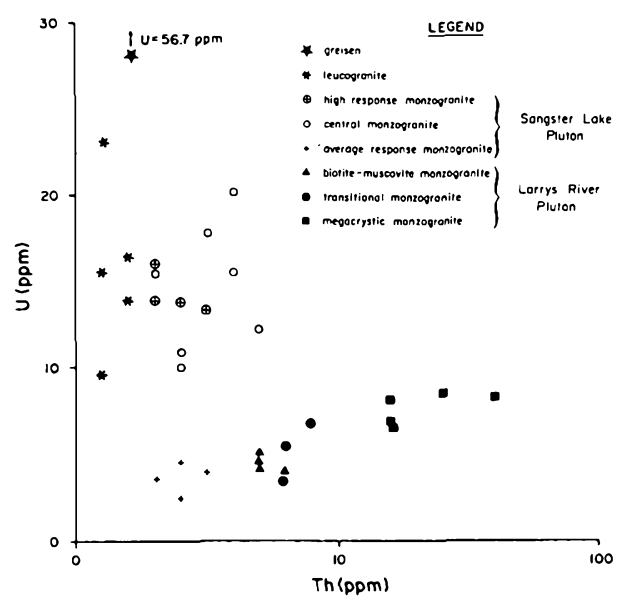

Fig. 6. Plot of $U$ versus Th for rock types and spectrometric categories of the Sangster Lake and Larrys R1ver plutons. Sample locations shown in Figure 5.

THE BIG INDIAN POLYPHASE INTRUSIVE SUITE

Geology

The B1g Indian Lake Polyphase Intrusive sulte (BIPI suite; F1g. 1), previously referred to as complex by Kontak and Corey (In press) and Corey (this volume), was discovered during bedrock mapping of the SMB (F1g. 7a; Corey, 1986; Ham and Horne, 1986). The BIPI suite is composed of two large $\left(18-20 \mathrm{~km}^{2}\right)$ monzogranitic bodies which have intruded blotite granodiorite. The monzogranite bodies consist of four compositionally and mineralogically similar, but texturally varlable 
types which include very fine grained (microgranite), fine- to medium-grained, medium- to coarse-grained, and porphyritic (Corey, this volume). These units are intimately associated, display sharp, Irregular contacts and are characterized by variable amounts of the hyperaluminous mineral assemblage muscovite, garnet, cordierite, andalusite and sillimanite. The ubiquitous presence of metasomatic garnet in particular is a reliable field parameter for distinguishing rocks of the BIPI suite from other monzogranites in the area (Kontak and Corey, in press).

Field and petrographic evidence indicates that mineralogical and textural modification occurred within rocks of the BIPI suite in response to early post-magmatic fluid-rock interaction (Corey, this volume). Although observed in all units, the metasomatic overprint is most intense and pervasive within the microgranite and those rocks adjacent to 1t. Furthermore, several different types and styles of mineralization and alteration occur within the BIPI suite. Readers are referred to Corey (this volume) for a more detalled discussion of the geology and mineralization of the BIPI suite.

\section{Airborne Spectrometric Response}

The airborne spectrometric coverage over the BIPI suite used in this study was complled from a 1986 detalled (250 $\mathrm{m}$ flight 1ine-spacing) airborne survey by the Geological Survey of Canada (Ford, 1987). The eU/eTh distribution patterns (Fig. 7b) are not as pronounced or varlable as those for the NRP. The highest ratio $(>0.95)$ anomaly is centered over an island in B1g Indian Lake, whereas the remainder of the BIPI suite is characterized by relatively low ratios $(<0.55)$.

Although the eU/eTh data over the BIPI sulte is of limited use, other spectrometric data do show a useful correlation. A plot of $\mathrm{eTh} / \mathrm{K}$ distribution (Fig. 7c) shows the BIPI suite to correlate with areas of anomalous1y low response $(<2)$, whereas the surrounding areas, predominantly granodiorite, are generally of much higher response $(>4)$. Thus, the $\mathrm{eTh} / \mathrm{K}$ ratio response in the BIPI sulte is reflecting either eTh depletion, and/or $K$ enrichment.

\section{Comparison of Spectrometric Response} with Geology

Comparison of the alteration features and the airborne spectrometric data for the BIPI suite indicate that the observed patterns of $e T h / K$ are significant (FIgs. 7a, c). The presence of syenogranite and widespread biotitization, K-feldspathization, sericitization and kaolinization within rocks of the BIPI suite (Corey, this volume) are consistent with the $\mathrm{K}_{2} \mathrm{O}$ enrichment trend 1llustrated in Figure 7c, and contribute to the low corresponding $e T h / K$ ratio response. In contrast to $K$, the behavior of Th during the alteration could not be determined from field observations. However, geochemical evidence (see below) shows an inverse relationship with $K_{2} 0$ in that $T h$ decreases with progressive alteration. Because Th decrease w111 also result in decrease of $T h / K$, this indicates that the observed spectrometric pattern is attributed to a combination of absolute increase and decrease in $K$ and $T h$, respectively.

\section{Lithogeochemical Comparison}

Geochemical data from samples of the BIPI suite verify the observed trends in the airborne spectrometric patterns (Figs. 8, 9). A plot of U versus Th (F1g. 8) shows decreasing Th with constant values of $U$, corresponding to the combined effects of differentiation and metasomatism within these rocks. However, it is important to note that the two samples which have the elevated $U$ content were much less disturbed by the metasomatism which overprinted these rocks (Corey, this volume). These two least disturbed samples are interpreted to best reflect the primary concentration of $U$ within the microgranite and monzogranite. This latter inference implies, therefore, that these rocks had an original trend of increasing $U$ and decreasing Th, whereas the other rocks have lost much of their $U$ due to hydrothermal leaching; much in the same way as Chatterjee et al. (1985) suggested for the Lewis Lake Leucogranite.

Additional data which 1llustrates the geochemical evolution of the BIPI suite is provided by trends of $\mathrm{Th} / \mathrm{U}$ versus $\mathrm{T} 1$ and $\mathrm{Zr}$ (not shown here) which are consistent with magmatic differentiation (1.e., decreasing $\mathrm{Th} / \mathrm{U}$ against decreasing $\mathrm{Zr}$ and $\mathrm{T} 1$ ).

The effects of pervasive metasomatism in the BIPI sulte have resulted in depletion of $U$ in a large volume of rock, thus lowering $U / T h$ and limiting the value of eU/eTh airborne surveys. However, as alluded to previously, the eTh/K pattern map (Fig. 7c) shows that rocks of the BIPI suite correlate with an area of low response for this ratio. Plots of $K$ versus $T h$ and $T h / K$ versus Th (Figs. 9a, b) verify the airborne patterns and show that the decrease of the $\mathrm{Th} / \mathrm{K}$ ratio is due to a combination of decreasing Th (magmatic differentiation) and increasing $\mathrm{K}$ (pervasive $\mathrm{K}$-metasomatism).

\section{SUMMARY AND CONCLUSIONS}

This study shows that airborne spectrometric surveys are a useful ald to both bedrock mapping and mineral exploration in granitic rocks similar to those of the MZ of Nova Scotia. This and some previous studies have confirmed that the observed radioelement patterns from the surveys reflect the actual proportions of $U, T h$ and $K$ in the bedrock.

Thickness and provenance of glaclal till cover are a significant factor to be considered. Any interpretation of airborne surveys must involve an understanding of the Pleistocene geology of the area in question. This study shows that airborne radiometric patterns over areas of locally derived tills reflect quite closely the underlying bedrock. By contrast, in areas underlain by far-travelled till the glacial cover has a shielding effect on the airborne radiometric response of the underlying bedrock.

The data presented here (especially for the NRP) show that airborne spectrometric surveys can distinguish areas of less evolved rocks (granodiorite and biotite monzogranite) from more evolved rocks (leucomonzogranite, leucograntte and some types of porphyry). In addition, the surveys, in some instances, can detect separate intrusions and areas of larger intrusions which have undergone late- and/or post-magmatic metasomat1sm and hydro- 

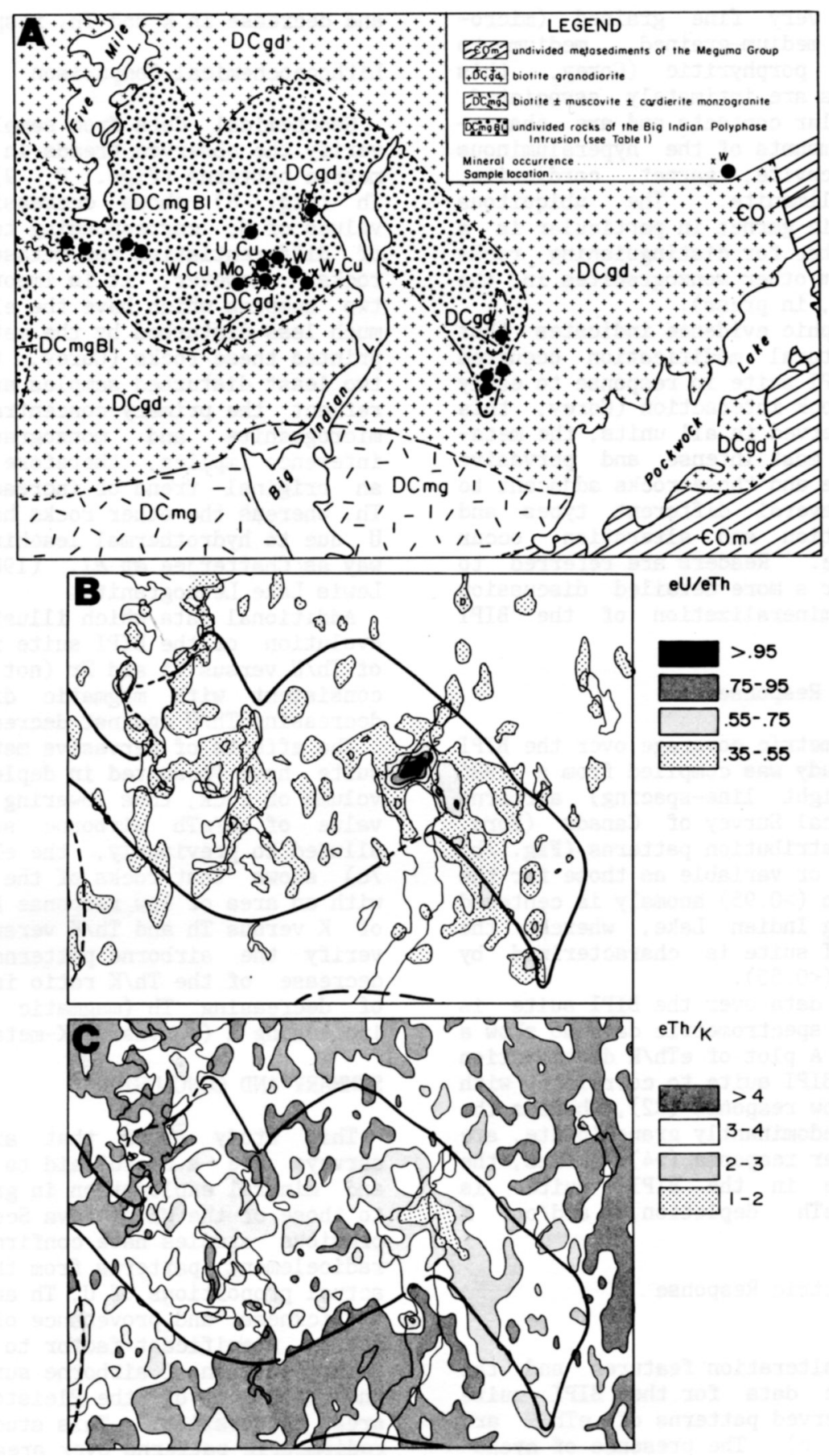

Fig. 7. Geologg map (A) and corresponding eU/eTh (B) and eTh/K (C) pattern maps for the Big Indian Polyphase Intrusive suite. See Figure 1 for location. Note: multiple samples were collected at several sample sites.

thermal alteration by a fluid phase (para-1ntrusive rock).

The ability of the surveys to help recognize areas of hydrothermally altered rocks is an important application for mineral exploration for granophile elements. Thus, while reglonal surveys such as those utilized in this study may not directly locate granophile element mineralization, they do provide a means to detect the areas of pervasive alteration which are often associated with these deposits. Geological, mineralogical and geochemical evidence has been presented which shows that these alteration processes often include enrichment and/or depletion of $U, T h$ and $K$. The overall compositional changes are of sufficient magnitude that they are detectable in the airborne spectrometric patterns. This particularly holds in areas with a high percentage of bedrock exposure and locally derived t111 cover. Detection of these altered areas provides excellent targets for mineral exploration for granophlle elements. However, this study also shows that mineralization 


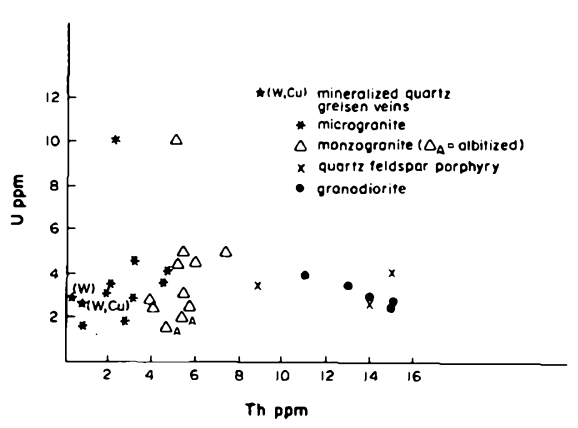

Fig. 8. Plot of $U$ versus Th for the Big Indian Polyphase Intrusive suite. Sample locations are shown on Figure 7.
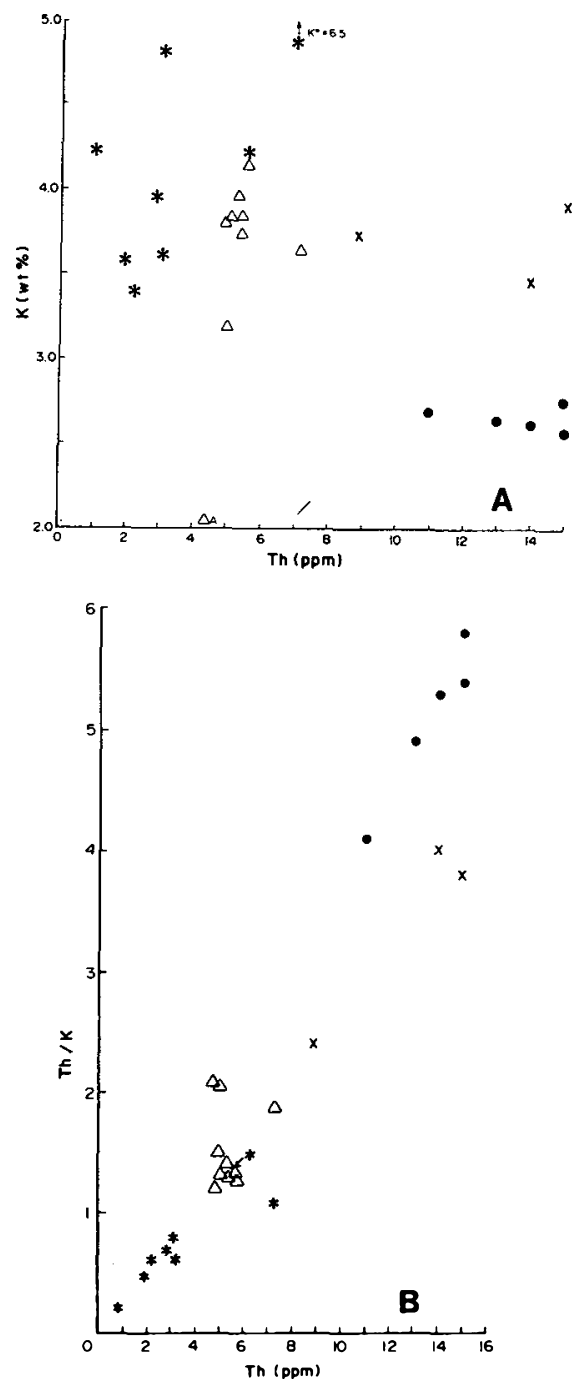

Fig. 9. Plots of $K$ versus $T h$ and $T h / K$ versus $T h$ for the Big Indian Polyphase Intrusive suite. Legend as in Figure 8. Sample locations are shown on Figure 7.

and associated alteration occurring within primitive units can escape detection by airborne surveys and instead await discovery by the geologically astute (or lucky) individual.

\section{ACKNOWLEDGEMENTS}

This study is the result of geological (0'Reilly and Corey) and geophysical (Ford) surveys carried out in Nova Scotia by the Nova Scotia Department of Mines and Energy and the Geological Survey of Canada under jointly funded Federal-Provincial Mineral Development Agreements since 1982. The authors especially thank the bedrock and Pleistocene mapping crews of the SMB project for support and many useful discussions. The manuscript has benefitted by reviews by Drs. J.D. H111 and D.J. Kontak, to whom the authors are grateful. Drafting of figures was provided by the cartographic section of the Nova Scotia Department of Mines and Energy.

BRISTOW, Q. 1979. Gamma-ray spectrometric methods in uranium exploration-airborne instrumentation. In Geophysics and Geochemistry in the Search for Metallic Ores. Edited by P.J. Hood. Geological Survey of Canada, Economic Geology Report 31. PP. 135-146.

CHARBONNEAU, B.W., KILLEEN, P.G., CARSON, J.M., CAMERON, G.W. , and RICHARDSON, K.A. 1976. Significance of radioelement concentration measurements made by airborne gamma-ray spectrometry over the Canadian Shield. IAEA Symposium on Exploration for Uranium Ore Deposits, Vienna, Austr1a, PD. 35-53.

CHAREST, M.H. 1976. Petrology, Geochemistry and Mineralization of the New Ross area, Lunenburg County, Nova Scotia. M.Sc. thesis, Dalhousie University, Halifax, Nova Scotia.

CHATTERJEE, A.K. 1983. Metallogenic map of Nova Scot1a, Nova Scot1a Department of Mines and Energy, Scale 1:500 000.

CHATTERJEE, A.K., and MUECKE, G.K. 1982. Geochemistry and the distribution of uranium and thorium in the granitold rocks of the South Mountain Batholith. Nova Scotia: some genetic and exploration 1mplications. In Uranium in Granites. Edited by Y.T. Maurice. Geological Survey of Canada, Paper 81-23, pp. $11-17$.

CHATTERJEE, A.K., STRONG, D.F., and MUECKE, G.K. 1985. A multivarlate approach to geochemical distinction between tinspecialized and uranium-specialized granites of southern Nova Scot1a. Canadian Journal of Earth Sciences, 20, pp. 420-430.

CHATTERJEE, A.K. STRONG D.F. CLARKB, D.B. . ROBERTSON, J. POLLOCK. D.. and MUECKE, G.K. 1985. Geochemistry of the granodiorite hosting uranium mineralization at Millet Brook. In Guide to Granites and Mineral Deposits of Southwestern Nova Scot1a. Edited by A.K. Chatterjee and D.B. Clarke. Nova Scot1a Department of Mines and Energy. Preprint of Paper 85-3. Pp. 63-114.

CLARKE, D.B., and HALLIDAY, A.N. 1980. Strontium 1sotope geology of the South Mountain Batholith, Nova Scotia. Geochimica et Cosmochimica Acta, 44, pp. 1045-1058.

CLARKE, D.B., and MUECKE, G.K. 1985. Review of the petrochemistry and or1gin of the South Mountain Batholith and assoc1ated plutons, Nova Scot1a, Canada. In H1gh Heat Production (HHP) Granites, Hydrothermal Circulation and Ore Genesis. Institution of Mining and Metallurgy. St. Auste11, Cornwall. England, pp. 41-54.

COREY M.C. 1986. Bedrock geology of the South Mountain Bathol1th: NTS Map Sheet 11D/13. In Mines and Minerals Branch, Report of Activities 1985. Edited by J.L. Bates. Nova Scot1a Department of Mines and Energy, Report 86-1, pp. 137-147.

COREY M.C. In preparat1on. Geology of the Chester map sheet. Nova Scotia Department of Mines and Energy, Open F1le Map 88001. Scale 1:50,000.

COREY. M.C. 1988. The occurrence of metasomatic aluminosilicates within the South Mountain Batholith: high alumina hydrothermal alteration. Maritime Sediments and Atlant1c Geology, 24. pp. 83-95.

FARLEY. E.J. 1978. Mineralization at the Turner and the Walker Deposits: South Mountain Batholith. M.Sc. thes1s, Dalhous1e University. Halifax, Nova Scotia.

FINCK, P.W. and GRAVES, R.M. In preparation. Glacial and till clast geology of Windsor map sheet, with accompanying margina notes and geochemistry. Nova Scotia Department of Mines anc Energy. Scale 1:50,000

FORD, K.L. 1982. Investigation of regional a1rborne gamma-ray spectrometric patterns in New Brunswick and Nova Scotia. In 
Current Research, Part B, Geological Survey of Canada, Paper 82-1B, pp. 177-194.

FORD, K.L. 1987. Airborne geophysical survey; gamma-ray spectrometric contour map and VLF-EM profile maps: B1g Indian Lake Area 11D/13. Geological Survey of Canada, Open F1le 1475. Scale 1:50,000

FORD, K.L., and BALLANTYNE, S.B. 1983. Urantum and thorium distribution patterns and 11thogeochemistry of Devonian granites in the Chedabucto Bay area, Nova Scot1a. In Current Research, Part A, Geological Survey of Canada, Paper 83-1A. pp. 109-119.

FORD, K.L., and O'REILLY, G.A. 1985. Airborne gamma-ray spectrometric surveys as an indicator of granophile element specialization and associated mineral deposits in the granitic rocks of the Meguma Zone of Nova Scotla. In High Heat Production (HHP) Granites. Hydrothermal Circulation and Ore Genesis. Inst1tution of Mining and Metallurgy. St. Auste11. Cornwall. England. pp. 113-133.

FYSON, W.K. 1966. Structures in the Lower Paleozolc Meguma Group. Nova Scotia. Geological Soc1ety of America Bulletin. 77. pp. 931-944.

GRASTY. R.L. 1979. Gamma-ray spectrometric methods in uranium exploration-theory and operational procedures. In Geophysics and Geochemistry in the Search for Metallic Ores. Edited by P.J. Hood. Geological Survey of Canada, Economic Geology Report 31, pp. 147-161.

GRAVES, R.M. and FINCK, P.W. In preparation. Glac1al and t111 clast geology of Chester map sheet, with accompanying marginal notes and geochemistry. Nova Scotla Department of Mines and Energy. Scale 1:50,000.

HAM, L.J., and HORNE, R.J. 1986. Geology of the South Mountain Bathollth on the eastern half of NTS Map Sheet $21 \mathrm{~A} / 16$. In Mines and Minerals Branch, Report of Activities 1985. Edited by J.L. Bates. Nova Scotia Department of Mines and Energy, Report 86-1. pp. 149-159.

HORNE. R.J. 1987. Preliminary geology of the New Germany map sheet 21A/10. Nova Scotla Department of Mines and Energy. Open File Map 87-004, Scale 1:50,000.

KEPPIE, J.D., and MUECKE, G.K. . Compllers. 1979. Metamorph1c map of Nova Scot1a. Nova Scotla Department of Mines and Energ8. Scale 1:1,000,000.

KILLEEN, P.G. 1979. Gamma-ray spectrometr1c methods in uranium exploration-application and interpretation. In Geophysics and Geochemistry in the Search for Metallic Ores. Edited by P.J. Hood. Geological Survey of Canada, Economic Geology Report 31. pp. 163-229.

KONTAK, D.J. 1987. The East Kemptville leucogranite: possible mid-Carboniferous topaz granite. In Mines and Minerals Branch, Report of Activities 1986. Edited by J.L. Bates and D.R. MacDonald. Nova Scotia Department of Mines and Energy, Report 87-1, pp. 81-94.

KONTAK, D.J., and COREY, M.C. In press. Metasomatic origin for spessartine-rich garnets in the South Mountain Batholith, Nova Scotia. Canadian Mineralogist, 26

LOGOTHETIS, J. 1984. The Mineralogy and Geochemistry of Metasomatized Rocks from Occurrences in the South Mountain Bathol1th: New Ross Area, Southwestern Nova Scotia. M.Sc. thes1s, Dalhousie University, Halifax, Nova Scotia, 359 p.

MACDONALD, M.A. , COREY, M.C., HAM, L.J., and HORNE, R.J. 1987a. The geology of the South Mountain Bathol1th: NTS map sheets $21 \mathrm{~A} / 09,21 \mathrm{~A} / 10,21 \mathrm{~A} / 15$ and $21 \mathrm{~A} / 16$ (west). In Mines and Minerals Branch, Report of Activities 1986. Edited by J.L. Bates and D.R. MacDonald. Nova Scotia Department of Mines and Energy, Report 87-1. pp. 107-122.

MACDONALD, M.A. , COREY, M.C., HAM, L.J., and HORNE, R.J. $1987 \mathrm{~b}$. The geology of the South Mountain Batholith: NTS map sheets $21 \mathrm{~A} / 09,21 \mathrm{~A} / 10,21 \mathrm{~A} / 15$ and $21 \mathrm{~A} / 16$ (west). In Mines and Minerals Branch, Report of Activities 1987. Part A. Edited by J.L. Bates and D.R. MacDonald. Nova Scot1a Department of Mines and Energy. Report 87-5, pp. 99-105.

MACDONALD. M.A., COREY, M.C., HAM, L.J., and HORNE, R.J. 1988.
Leucogranite and leucomonzogranite in the South Mountain Batholith, southwestern Nova Scot1a. In Program with Abstracts, Atlantic Geoscience Soclety Colloquium ' 88 Antigonish. Nova Scotia.

MCKENZIE, C.B., and CLARKE, D.B. 1975. Petrology of the South Mountain Batholith, Nova Scotia. Canadian Journal of Earth Sclences, 12, pp. 1209-1218.

MUECKE, G.K. and CLARKE, D.B. 1981. Geochemical evolution of the South Mountain Batholith. Nova Scotla: rare earth element evidence. Canadian Mineralog1st, 19. pp. 133-145.

O'REILLY, G.A. 1984. Geology of the Sangster Lake and Larrys River Plutons. In Mines and Minerals Branch, Report of Act1vities 1983. Edited by J. Szostak and K.A. M11ls. Nova Scotia Department of Mines and Energy, Report 84-1, pp. 231235

0'REILLY, G.A. 1985. Geochemical varlation within a granitic terrane displaying anomalous airborne radiometric signature from eastern Nova Scotia. In Mines and Minerals Branch, Report of Activities 1984. Edited by K.A. Mills and J.L. Bates. Nova Scotia Department of Mines and Energy. Report 851. pp. 135-142.

O'REILLY, G.A. FARLEY, E.J., and CHAREST, M.H. 1982. Metasomat1c-hydrothermal mineral deposits of the New Ross-Mahone Bay area, Nova Scotia. Nova Scot1a Department of Mines and Energy, Paper 82-2, $96 \mathrm{p}$.

O'REILLY, G.A., GAUTHIER, G., and BROOKS, C. 1985. Three Permo-Carboniferous $\mathrm{Rb} / \mathrm{Sr}$ age determinations from the South Mounta1n Bathol1th. In Mines and Minerals Branch, Report of Act1vit1es 1984. Edited by K.A. M11ls and J.L. Bates. Nova Scotia Department of Mines and Energy. Report 85-1, Pp. 143152

PALMER, M.G.B. 1980. Report on geological, so1l, rock and radon geochemical surveys, ground VLF and magnetic surveys, trenching and drilling. New Ross, Lunenburg County, Nova Scot1a. Can-Lake Exploration Limited, Nova Scotia Department of M1nes and Energy. Assessment Report 21A/9C. 54-L-19(05). $150 \mathrm{p}$.

POLLARD, P.J. 1983. Magmat1c and post magmat1c processes in the formation of rocks associated with rare-elament deposits. Transactions Institution of Mining and Metallurgy. Section B. 92, pp. B1-B9.

REYHOLDS, P.H. , ZENTILLI, M. , and MUECKE, G.K. 1981. K-Ar and $\mathrm{Ar} /{ }^{39} \mathrm{Ar}$ geochronology of granitold rocks from southern Nova Scot1a: Its bearing on the geological evolution of the Meguma Zone of the Appalachians. Canadian Journal of Earth Sciences. 18, pp. 386-394

REYNOLDS, P.H. ELIAS, P., MUECKR, G.K. , and GRIST, A.M. 1987 Thermal history of of the southwestern Meguma Zone, Nova Scotia, from a ${ }^{40} \mathrm{Ar} /{ }^{39} \mathrm{Ar}$ and fission track dating study of intrusive rocks. Canadian Journal of Earth Sciences, 24. pp. 1952-1965.

RICHARDSON, J.M.G., SPOONER, E.T.C. , and MCAUSLAN, D.A. 1982. The East Kemptville tin deposit. Nova Scot1a: an example of a large tonnage. low grade greisen hosted deposit in the endocontact zone of a granite batholith. In Current Research. Part B, Geological Survey of Canada, Paper 82-1B, pp. 27-32.

SCHENK, P.E. 1971. Southeastern Atlant1c Canada, northwestern Africa, and continental drift. Canadian Journal of Earth Sciences, 8, pp. 1218-1252.

STRECKEISEN, A. 1976. To each plutonic rock 1ts proper name. Earth Sclence Review, 12, pp. 1-33.

TAYLOR, F.C. 1969. Geology of the Annapol1s-St. Marys Bay Map Area, Nova Scot1a (21A, 21B, east half). Geological Survey of Canada, Memo1r 358, 65 p.

WILLIAMS, H. 1978. Tectonic 11thofacies map of the Appalachian Orogen. Memorlal Untversity of Newfoundland. Map 1. Scale

ZENTILLI, M. , and REYNOLDS, P.H. 1985. ${ }^{40} \mathrm{Ar} /{ }^{39} \mathrm{Ar}$ dating of micas from the East Kemptville tin deposit, Yarmouth County. Nova Scotia. Canadian Journal of Earth Sciences, 22, pp. 1546-1548. 